\title{
FACTORS WHICH AFFECTING FARMERS IN SALES THE HARVEST PADDY TO THE MIDDLEMEN IN LAJUK VILLAGE, GONDANGWETAN, PASURUAN
}

\author{
Tatang Suryadi ${ }^{1)}$, Latarus Fangohoi ${ }^{1)}$, Djamaluddin Tuahuns ${ }^{2)}$ \\ ${ }^{1)}$ Dosen STPP Malang \\ 2) Mahasiswa Program Diploma STPP Malang \\ email : suryadist12@yahoo.co.id
}

\begin{abstract}
ABSTRAK
Faktor-Faktor Yang Mempengaruhi Petani Dalam Penjualan Hasil Panen Gabah ke Tengkulak Di Desa Lajuk Kecamatan Gondangwetan Kabupaten Pasuruan. Sebagian besar penduduk di Desa Lajuk Kecamatan Gondangwetan sebagian besar adalah petani. Dalam melakukan aktifitasnya sebagai petani ,senantiasa masih tergantung pada tengkulak untuk memfasilitasi usahataninya. Tujuan dari penelitian ini adalah untuk mengetahui variabel variabel yang mempengaruhi keputusan penjualan gabah ke tengkulak, yaitu, produksi Padi, Perbedaan Harga, Kebutuhan keluarga. Sedangkan metode yang digunakan adalah metode wawancara dan kuesioner. Pengambilan sampel menggunakan cara acak yang ditentukan atau secara sengaja ( Purposive Random Sampling ) Sampel yang digunakan adalah 34 responden dengan hasil penelitian yaitu produksi padi, perbedaan harga ,dan kebutuhan keluarga dengan $\mathrm{F}_{\text {tabel }}=2,92$ serta $F_{\text {hitung }} 23,301$ maka terdapat pengaruh secara bersama-sama terhadap penjualan gabah ke tengkulak. Namun secara partial variabel perbedaan harga berpengaruh secara negatif terhadap penjualan hasil gabah ke tengkulak. Sedangkan secara stimultan variabel yang paling berpengaruh terhadap penjualan gabah ke tengkulak yaitu variabel produksi padi , $X_{1}=3,285$, variabel perbedaan harga, $X_{2}=-0,654$, dan variabel kebutuhan keluarga, $X_{3}=2,531$.
\end{abstract}

Kata kunci : Petani, Penjualan, Gabah dan Tengkulak

\begin{abstract}
Factors Affecting Farmers in the Sale of Harvest Grain to Brokers In Lajuk Village, Gondangwetan District, Pasuruan Regency. Most of the people in Lajuk Village, Gondangwetan District are mostly farmers. In doing its activities as a farmer, always depends on the middleman to facilitate his farming. The purpose of this study is to determine the variables that affect the decision of the sale of grain to the middleman, that is, the production of Rice, Price Differences, Family Needs. While the method used is the method of interviews and questionnaires. Sampling used was purposed random sampling (purposive random sampling) The sample used was 34 respondents with the result of research that is rice production, price difference, and family need with $F_{\text {tabel }}=2,92$ and $F_{\text {hitung }} 23,301$ hence there is influence together to the sale of grain to middlemen. However, partially variable price differences negatively affect the sale of grain to middlemen. While the most influential variable stimuli to the sale of grain to the middlemen are rice production variables, $\mathrm{X} 1=$ 3.285 , variable price differences, $\mathrm{X} 2=-0.654$, and variable needs family, $\mathrm{X} 3=2,531$.
\end{abstract}

Keywords: Farmer, Sales, Grain, and Middleman 


\section{PENDAHULUAN}

Indonesia merupakan Negara agraris, yang dimana sumber mata pencaharian utama masyarakatnya adalah di bidang pertanian atau biasa disebut juga dengan Negara pertanian, yang berarti pertanian sangat berperan penting dari keseluruhan perekonomian nasional. Hal ini disebabkan oleh letak geografis Indonesia yang berada di daerah tropis, dengan keadaan cuaca, tanah dan sumber daya lainnya yang memiliki potensi yang cukup tinggi untuk pengembangan kesejahteraan masyarakat terutama sektor pertanian.

Pendayagunaan sumberdaya pertanian di Indonesia menjadi kunci untuk meningkatkan produktivitas pertanian sehingga sumberdaya yang terbatas itu harus dialokasikan seefisien mungkin,semuanya itu dapat dilihat dari banyaknya penduduk atau tenaga kerja yang hidup atau bekerja pada sektor pertanian atau produk nasional yang berasal dari pertanian. Sumberdaya pertanian biasanya terdiri dari lahan, tenaga kerja, air, termasuk juga unsur yang terkandung di dalamnya merupakan sumberdaya yang utama untuk kelangsungan hidup manusia,pengelolaan yang tidak bijaksana akan berakibat menurunnya kualitas sumberdaya itu sendiri yang akhirnya berpengaruh terhadap produktivitas pertanian.

Berbagai persoalan yang sering di hadapi oleh petani baik yang berhubungan secara langsung dengan produksi dan pemasaran hasil pertaniannya maupun yang dihadapi dalam kehidupan seharihari,sehingga tidak hanya aspek ekonomi saja akan tetapi aspek-aspek sosial, kebudayaan, aspek kepercayaan dan keagamaan serta aspek-aspek tradisi semuanya memegang peranan penting untuk perilaku petani dalam penjualan. Sebagian besar petani sering menghadapi permasalahan yang terjadi diantaranya harga produksi dan pemasaran hasil yang dirasakan sangat mahal serta modal petani yang dimiliki sangat minim dalam usahatani padinya. Masalah yang dihadapi petani adalah harga hasil penjualan padi yang sering tidak stabil, tentunya sangat merugikan para petani karena harga bahanbahan produksi seperti pupuk dan obatobatan cenderung mengalami kenaikan. Sementara akses pemasaran dan permodalan, para petani juga sering mengalami hal yang merugikan, bahkan para petani harus terjebak ke dalam sistem pemasaran dan permodalan yang menguntungkan satu pihak saja dalam hal ini para tengkulak.

Secara umum hasil penjualan petani belum memadai dibandingkan dengan kerja keras yang dilakukan selama proses penanaman padi,dan ditambah lagi dengan resiko kegagalan panen. Namun pada tahun 2014, pemerintah Indonesia dalam hal ini Kementerian Pertanian, menyelenggarakan program UPSUS PAJALE dengan tujuan untuk meningkatkan produktivitas dan penghasilan petani padi di pedesaan, dengan memberikan bantuan berupa bibit,pupuk,alat mesin pertanian,dan biaya produksi untuk petani kecil agar tercapai kesejahteraan hidupnya dan terhindar dari praktek tengkulak di pedesaan,akan tetapi dalam rangka meningkatkan produktivitas petani dan meningkatkan hasil penjualan ini kenyataannya masyarakat masih saja tergantung kepada tengkulak,sehingga peran pemerintah dalam hal tersebut belum tercapai maksimal dengan apa yang diharapkan.

Desa Lajuk merupakan salah satu desa yang berada di Kecamatan Gondangwetan Kabupaten Pasuruan dimana mayoritas penduduknya bermata pencaharian sebagai petani dan menggantungkan hidupnya di sektor pertanian. Petani dapat merasakan hasil panen tiga kali dalam satu tahun,desa lajuk memiliki luas tanam serta luas panen padi 133,68 Ha,dengan produksi padi 828,816 $\mathrm{Kg}$ dan produktivitas 6,2 ton/ha.

Kehidupan petani yang bergantung pada tengkulak inilah yang membuat peneliti tertarik untuk meneliti. Kondisi pertanian padi di Desa Lajuk Kecamatan Gondangwetan menggambarkan pemilik modal utamanya adalah tengkulak sehingga sangat menentukan berhasil tidaknya kegiatan pertanian di Desa tersebut. Bila 
dilihat dari usaha pertanian di Desa Lajuk, maka para tengkulak hampir berpengaruh sepenuhnya. Dari identifikasi awal tersebut, peneliti melihat bahwa petani mengetahui bahwa dengan menjual hasil panen ke BULOG atau RMU lebih untung ketimbang di tengkulak yang bisa mempengaruhi kehidupan ekonominya, akan tetapi petani tidak mampu untuk memperbaiki keadaan tersebut. Berdasarkan hal tersebut peneliti merasa tertarik untuk mengetahui variabel variabel yang mempengaruhi petani dalam penjualan gabah ke tengkulak di Desa Lajuk Kecamatan Gondangwetan Kabupaten Pasuruan.

\section{METODE PENELITIAN}

Pemilihan daerah penelitian dilakukan secara purposive sampling dengan pertimbangan bahwa (1) belum pernah dilakukan penelitian ini di Desa Lajuk dan daerah ini merupakan salah satu sentra pengembangan produksi padi di daerah Pasuruan; dan (2) Terdapat banyak petani sebagai petani penebas dalam penjualan padinya.

Penelitian ini dilaksanakan di Desa Lajuk, Kecamatan Gondangwetan, Kabupaten Pasuruan.Pada bulan April sampai dengan Juni 2016. Sasaran penelitian adalah petani padi di Desa Lajuk Kecamatan Gondangwetan Kabupaten Pasuruan. Teknik pengambilan sampel penelitian adalah petani padi yang jumlah populasi sebanyak 103 orang, dengan menggunakan metode purposive random sampling yaitu pengambilan sampel berdasarkan wilayah dimana masingmasing bagian diambil sampelnya secara acak, karena Desa Lajuk terdiri dari tiga dusun diantaranya dusun Murjati, Rekesan dan Krajan, sehingga diperoleh jumlah sampel petani sebanyak 34 orang, dengan proporsi berdasarkan jumlah populasi dari masing masing dusun.

Pengambilan sampling ini dihitung dengan rumus Slovin yaitu :

$$
n=\frac{N}{1+N e^{2}}
$$

Keterangan:

$$
\begin{aligned}
& \mathrm{n}=\text { Jumlah Sampel } \\
& \mathrm{N}=\text { Jumlah Populasi (103 orang) } \\
& \mathrm{e}^{2}=\text { Presisi yang ditetapkan dengan } \\
& \text { tingkat presisi yang ditetapkan } \\
& \text { sebesar( }\left(\mathrm{e}^{2}\right)=15 \%,
\end{aligned}
$$

\section{HASIL DAN PEMBAHASAN}

\section{Analisis Data}

\section{a. Analisis Regresi Linear Berganda}

Untuk menguji hipotesis pertama dalam regresi linear berganda dengan menggunakan program SPSS 20.

\section{Data keluaran.}

Dalam metode analisis regresi linear berganda terdapat tiga variable yaitu produksi padi $\left(\mathrm{X}_{1}\right)$, perbedaan harga (X2), dan kebutuhan keluarga $\left(X_{3}\right)$. Dari ketiga variable yang dimasukan tersebut tidak ada yang dikeluarkan (removed). Hal ini disebabkan karena menggunakan metode singlestep (enter) yang dimana dalam menganalisis data hanya dalam satu kali proses atau sekaligus menganalisa. 
Tabel 1. Coefficients ${ }^{\mathrm{a}}$

\begin{tabular}{|c|c|c|c|c|c|c|}
\hline \multirow{2}{*}{\multicolumn{2}{|c|}{ Model }} & \multicolumn{5}{|c|}{$\begin{array}{l}\text { Standardized } \\
\text { Coefficients }\end{array}$} \\
\hline & & $\mathrm{B}$ & $\begin{array}{l}\text { Std. } \\
\text { Error }\end{array}$ & Beta & $\mathrm{t}$ & Sig. \\
\hline 1 & (Constant) & 4.395 & 1.837 & & 2.393 & 0.023 \\
\hline & Produksi Padi (X1) & 0.082 & 0.025 & 0.503 & 3.285 & 0.003 \\
\hline & Perbedaan harga (X2) & -0.243 & 0.372 & -0.07 & -0.654 & 0.518 \\
\hline & Kebutuhan Keluarga X3) & 0.164 & 0.065 & 0.399 & 2.531 & 0.017 \\
\hline
\end{tabular}

a . Dependent Variable: Penjualan

Padi Ke Tengkulak (Y)

\section{Data Koefisien}

Koefisien dapat dilihat bahwa nilai konstanta persamaan linear berganda yang digunakan dalam penelitian ini yaitu $\mathrm{Y}=4,395+0,082 \mathrm{X} 1+(-0,243) \mathrm{X} 2+0,164 \mathrm{X} 3$. Maka persamaan diatas dapat diartikan sebagai berikut :

a) Konstanta sebesar 4,395 artinya bila produksi padi $\left(\mathrm{X}_{1}\right)$, Perbedaan harga $\left(\mathrm{X}_{2}\right)$, dan kebutuhan keluarga $\left(\mathrm{X}_{3}\right)$ adalah 0,maka petani akan menjual hasil panen padi kepada tengkulak (Y) yang nilai positifnya adalah 4,395.

b) Koefisien regresi produksi padi $\left(\mathrm{X}_{1}\right)$ memiliki nilai sebesar 0,082 , jika setiap kenaikan produksi padi dalam satuan maka terjadi kenaikan juga dalam penjualan padi ke tengkulak sebesar $0,082 \mathrm{~kg}$.

Tabel 2. Model Summary

\begin{tabular}{|c|c|c|c|c|c|c|c|c|c|c|}
\hline \multirow[b]{2}{*}{ Model } & \multirow[b]{2}{*}{$\mathrm{R}$} & \multirow[b]{2}{*}{$\begin{array}{c}\mathrm{R} \\
\text { Square }\end{array}$} & \multirow{2}{*}{$\begin{array}{c}\text { Adjusted } \\
\text { R } \\
\text { Square }\end{array}$} & \multirow{2}{*}{$\begin{array}{l}\text { Std. Error } \\
\text { of the } \\
\text { Estimate }\end{array}$} & \multicolumn{5}{|c|}{ Change Statistics } & \multirow{2}{*}{$\begin{array}{l}\text { Durbin- } \\
\text { Watson }\end{array}$} \\
\hline & & & & & $\begin{array}{c}\mathrm{R} \\
\text { Square } \\
\text { Change }\end{array}$ & $\begin{array}{c}\mathrm{F} \\
\text { Change }\end{array}$ & df1 & df2 & $\begin{array}{c}\text { Sig. F } \\
\text { Change }\end{array}$ & \\
\hline 1 & $.836^{a}$ & 0.700 & 0.670 & 0.819 & 0.700 & 23.301 & 3 & 30 & 0.00 & 1.580 \\
\hline
\end{tabular}

a. Predictors: (Constant), Kebutuhan Keluarga, Perbedaan Harga, Produksi Padi

b. Dependent Variable: Penjualan Padi Ke Tengkulak

c) Koefisien regresi perbedaan harga $\left(\mathrm{X}_{2}\right)$ memiliki nilai sebesar -0,243, jika terjadi kenaikan harga transportasi tidak sebanding dengan perubahan harga dalam satuan maka terjadi penurunan dalam penjualan padi ke tengkulak sebesar $-0,243 \mathrm{~kg}$.

d) Koefisien regresi kebutuhan keluarga $\left(X_{3}\right)$ memiliki nilai sebesar 0,164,jika setiap kenaikan kebutuhan keluarga dalam satuan maka akan terjadi kenaikan dalam penjualan padi ke tengkulak sebesar $0,164 \mathrm{~kg}$.

\section{Data Model Summary}

Berdasarkan hasil diketahui bahwa besarnya kontribusi variabel yang didapat dari koefisien determinasi. Maka nilai $\mathrm{R}$ Square atau R 2 (koefisien determinasi) hasil regresi diperoleh nilai $\mathrm{R}$ Square $=$ 0,700, hasil tersebut menunjukkan bahwa pengaruh secara bersama-sama antara produksi padi $\left(\mathrm{X}_{1}\right)$, Perbedaan harga $\left(\mathrm{X}_{2}\right)$, kebutuhan keluarga $\left(\mathrm{X}_{3}\right)$ terhadap penjualan padi kepada tengkulak sebesar 70 persen. Sedangkan sisanya sebesar sebesar 30 persen (100-30) dipengaruhi oleh variabel lain yang tidak diteliti. 
Tabel 3. ANOVA ${ }^{a}$

\begin{tabular}{|c|c|c|c|c|c|c|}
\hline Model & & $\begin{array}{c}\text { Sum of } \\
\text { Squares }\end{array}$ & df & Mean Square & $\mathrm{F}$ & Sig. \\
\hline \multirow{3}{*}{ 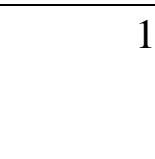 } & Regression & 46.84 & 3 & 15.613 & 23.301 & $.000^{\mathrm{b}}$ \\
\hline & Residual & 20.102 & 30 & 0.67 & & \\
\hline & Total & 66.941 & 33 & & & \\
\hline
\end{tabular}

a. Dependent Variable: Penjualan Padi Ke Tengkulak

b. Predictors: (Constant), Kebutuhan Keluarga, Perbedaan Harga, Produksi Padi

\section{Uji F ( Secara Simultan )}

Hasil uji $\mathrm{F}$ dari koofisien regresi diperoleh hasil $F_{\text {hitung dari model summary }}$ 23,301 dengan tingkat signifikan 0,000. Maka untuk nilai $\mathrm{F}$ tabel dengan $\mathrm{N}_{1}$ adalah df pembilang sebesar 3 dan $\mathrm{N}_{2}$ adalah df penyebut sebesar 30 maka diperoleh $\mathrm{F}_{\text {tabel }}$ 2,92. Dengan hasil tersebut maka $F_{\text {hitung }}>$ dari $\mathrm{F}_{\text {tabel }}$ atau 23,301 $>2,92$ dan nilai signifikansi sebesar $0,000<$ dari 0,05 maka $\mathrm{H}_{0}$ di terima dan $\mathrm{H}_{1}$ ditolak karena terdapat pengaruh secara simultan (bersama-sama) antara produksi padi $\left(\mathrm{X}_{1}\right)$,perbedaan harga $\left(\mathrm{X}_{2}\right)$,dan kebutuhan keluarga $\left(\mathrm{X}_{3}\right)$ terhadap penjualan padi ke tengkulak (Y). Namun secara partial variabel perbedaan harga $\left(\mathrm{X}_{2}\right)$ berpengaruh negatif dengan signifikan terhadap penjualan hasil panen gabah ke tengkulak.

Pendapatan petani hanya diterima pada setiap musim panen saja,sementara pengeluaran untuk kebutuhan hidup maupun produksi padi sangat penting, sehingga petani kebanyakan bisa memenuhi keperluannya itu pada saat masa panen saja. Sementara ketergantungan ketengkulak, petani tidak merasakan pemasaran dengan KUD,RMU maupun BULOG yang dalam hal ini merupakan program pemerintah dalam swasembada pangan dikarenakan petani harus membawa sendiri ke KUD,RMU atau BULOG dan juga standar air juga harus sesuai dengan yang ditetapkan.

\section{Uji T ( Secara Parsial)}

Uji t diperlukan untuk mengetahui apakah terjadi pengaruh antara produksi padi $\left(\mathrm{X}_{1}\right)$,Perbedaan harga $\left(\mathrm{X}_{2}\right)$,dan kebutuhan keluarga $\left(\mathrm{X}_{3}\right)$ terhadap penjualan hasil panen gabah ke tengkulak (Y),dengan demikian tingkat kepercayaan dipakai sebesar $95 \%$ dengan derajat kebebasan (degree of freedom) df adalah 3 sebagai pembuktiannya. Sedangkan untuk uji dua sisi menggunakan :

$$
\begin{aligned}
& \alpha 5 \%=0,05 / 2=0,025 \\
& \text { Dimana : } \quad \text { df }=n-3 \\
& =34-3 \\
& =31
\end{aligned}
$$

Tabel 4. Coefficients ${ }^{\mathrm{a}}$

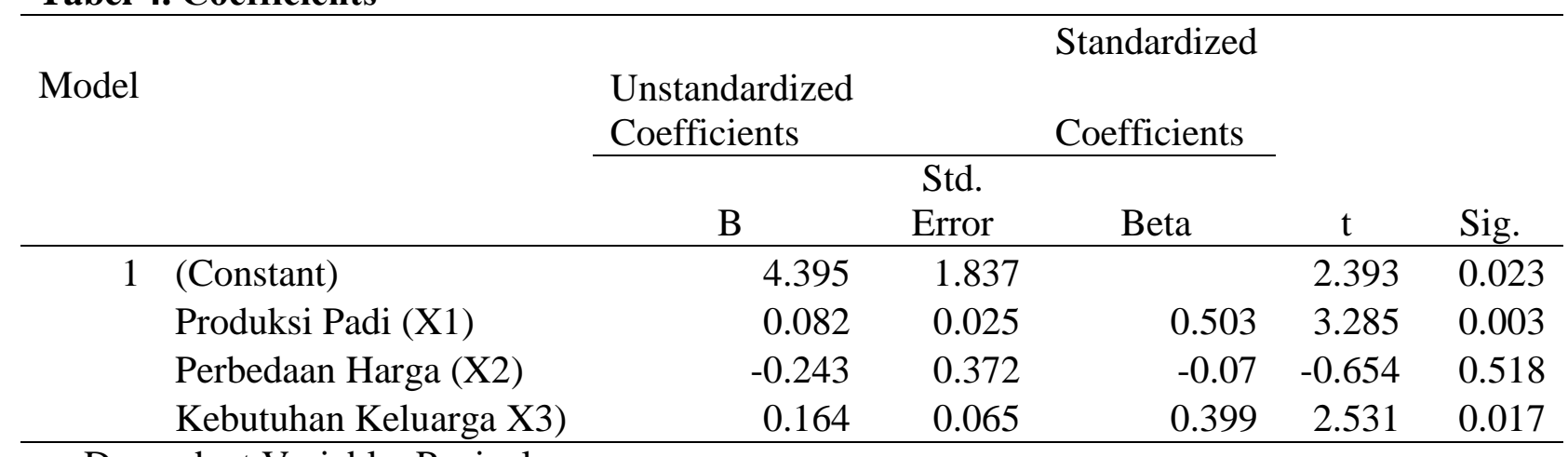

a . Dependent Variable: Penjualan

Padi Ke Tengkulak (Y) 
a. Berdasarkan uji hipotesis yang dapat dilihat dari tabel koofisien dengan menggunakan uji t,maka nilai $t_{\text {hitung }}$ untuk koofisien produksi padi $\left(\mathrm{X}_{1}\right)$ yaitu 3,285 dengan nilai signifikansi 0,003 . Nilai $t_{\text {tabel }}$ untuk pengujian signifikansi dapat diperoleh dengan nilai alpha 5\% dan df sebesar 31 maka diperoleh nilai $t_{\text {tabel }}$ adalah 2,069, Dengan keputusan bila $t_{\text {hitung }}>t_{\text {tabell }}$ maka $\mathrm{H}_{0}$ diterima dan $\mathrm{H}_{1}$ ditolak. Maka $t_{\text {hitung }}(3,285)>t_{\text {tabel }}(2,069)$ sehingga $\mathrm{H}_{0}$ diterima yaitu terdapat pengaruh positif antara produksi padi $\left(\mathrm{X}_{1}\right)$ dengan penjualan hasil panen gabah ke tengkulak (Y). Hal ini disebabkan terdapat faktor produksi luas lahan $70,59 \%$,tenaga kerja $47,06 \%$ dan modal $47,06 \%$. Jika dilihat maka faktor produksi diatas mempengaruhi jumlah produksi.semakin banyak yang diproduksi maka membutuhkan modal kembali lebih banyak sehingga harus segera dijual untuk memperoleh modal kembali sebagai modal usaha kembali, sehingga kebutuhan untuk masa tanam berikutnya memerlukan modal untuk biaya produksi.

b. Nilai koefisien Perbedaan harga $\left(X_{2}\right)$ adalah $-0,654$ dengan nilai signifikansi sebesar 0,581. Nilai $t_{\text {tabel }}$ untuk pengujian signifikansi 0,581 dapat diperoleh dengan nilai alpha 5\% dan df sebesar 31 maka diperoleh nilai $t_{\text {tabel }}$ adalah 5,879. Dengan keputusan bila $t_{\text {hitung }}>t_{\text {tabel }}$ maka $\mathrm{H}_{0}$ diterima dan $\mathrm{H}_{1}$ ditolak, maka bila thitung $(-0,654)<$ $t_{\text {tabel }}(5,879)$ sehingga Ho ditolak dan Hi diterima yaitu terdapat pengaruh negatif antara Perbedaan harga $\left(\mathrm{X}_{2}\right)$, dengan penjualan hasil panen gabah ke tengkulak (Y). Hal ini disebabkan karena kebutuhan akan biaya transportasi menjadi beban petani untuk menjual ke tengkulak yang agak jauh yang memberikan harga lebih tinggi yang diterima petani, namun bila harga tersebut perbedaannya tidak jauh dengan harga tengkulak yang lebih deket dengan harga yang lebih murah maka petani menjual pada tengkulak yang lebih dekat sehingga perbedaan harga tersebut tidak mempengaruhi keputusan petani untuk menjual padi bila dikaitkan dengan biaya transportasi yang harus dikeluarkan.

Nilai koefisien $t_{\text {hitung }}$ kebutuhan keluarga $\left(\mathrm{X}_{3}\right)$ adalah 2,531 dengan nilai signifikansi sebesar 0,017. Nilai tabel untuk pengujian signifikansi dapat diperoleh dengan nilai alpha 5\% dan df sebesar 31 maka diperoleh nilai $t_{\text {tabel }}$ adalah 1,390. Dengan keputusan bila $t_{\text {hitung }}>t_{\text {tabel }}$ dan signifikansi thitung $>$ $\mathrm{t}_{\text {tabel }}$ maka $\mathrm{H}_{0}$ diterima dan $\mathrm{H}_{1}$ diterima, $t_{\text {hitung }}(2,531)>t_{\text {tabel }}(1,390)$ sehingga $\mathrm{H}_{0}$ diterima yaitu terdapat pengaruh positif antara kebutuhan keluarga $\left(\mathrm{X}_{3}\right)$ dengan penjualan hasil panen gabah ketengkulak (Y).Hal ini sangat berhubungan erat dengan kebutuhan keluarga $\left(\mathrm{X}_{3}\right)$,yang dimana faktor biaya makan 32,35\% dan faktor biaya pendidikan 35,29\%,merupakan kebutuhan dasar bagi petani. Sehingga untuk memenuhi kebutuhan tersebut diperlukan pinjaman ke tengkulak dan harus mengembalikan ke tengkulak dalam bentuk padi yang harus dijual.

\section{c. Uji Hipotesis Kedua}

Bila dilihat dari hipotesis pertama maka dapat disimpulkan bahwa diantara varibel produksi padi $\left(\mathrm{X}_{1}\right)$,Perbedaan harga $\left(\mathrm{X}_{2}\right)$,dan kebutuhan keluarga $\left(\mathrm{X}_{3}\right)$ mana diantara yang paling berpengaruh terhadap penjualan hasil panen gabah ketengkulak sebagai berikut :

$$
\begin{array}{ll}
\text { Nilait }_{\text {hitung }} X_{1} & =3,285 \\
\text { Nilait }_{\text {hitung }} & =-0,654 \\
\text { Nilait }_{\text {hitung }} & =2,531
\end{array}
$$

Berdasarkan dari uraian nilai thitung diatas maka nilai yang paling terbesar adalah $X_{1}$. Jadi variabel yang paling berpengaruh terhadap penjualan hasil panen gabah ke tengkulak (Y) adalah Produksi padi $\left(\mathrm{X}_{1}\right)$.yang kedua adalah variabel Kebutuhan hidup ( X3 ) dan yang ketiga yaitu Perbedaan harga yang memberikan nilai selisih lebih tinggi setelah dikurangi biaya transportasi ( X2)

Pada umumnya petani di Desa Lajuk Kecamatan Gondangwetan menjual padi pada saat panen atau setelah panen dengan 
keadaan gabah kering panen ini dikarenakan petani sangat membutuhkan uang tunai untuk memenuhi biaya produksi pada masa tanam berikutnya dan kebutuhan hidup keluarganya sehari-hari sehingga mereka harus tergantung kepada tengkulak sebagai pembeli.

\section{KESIMPULAN}

Kesimpulan yang dapat diambil dalam penelitian ini adalah :

Variabel yang mempengaruhi penjualan padi ke tengkulak adalah variabel produksi padi $\left(\mathrm{X}_{1}\right)$ dimana terdapat faktor modal, sebagai kebutuhan untuk masa tanam berikutnya memerlukan modal untuk biaya produksi.

Faktor modal sangat berhubungan erat dengan kebutuhan keluarga $\left(\mathrm{X}_{3}\right)$,yang dimana faktor biaya makan dan faktor biaya pendidikan merupakan kebutuhan dasar bagi petani. Sehingga untuk memenuhi kebutuhan tersebut diperlukan pinjaman ke tengkulak.

Oleh sebab itu, apabila petani punya harapan mejual padinya keluar dengan perbedaan harga ( X3 ) yang lebih tinggi, maka petani akan menjual padinya keluar dengan pertimbangan bila harga jual tersebut masih ada selisihnya bila dikurangi dengan biaya transportasinya, bila tidak maka petani akan menjual pada tengkulak terdekat dengan tanpa biaya trasportasi.

\section{SARAN}

Saran yang dapat diajukan pada penelitian ini yaitu:

1. Untuk melakukan peningkatan pendapatan petani perlunya peran aktif dari jajaran BULOG dalam pembelian gabah petani.

2. Untuk Pemerintah Daerah Kabupaten Pasuruan agar memfasilitasi modal petani melalui pelaku usaha,yangselama dianggap sulit dalam peminjaman modal melalui BANK,KOPERASI dan lain-lain.

\section{DAFTAR PUSTAKA}

Anak Tani, (2015).Pengertian Pertanian.http://www.budidayapeta ni.com/2015/06 pengertianpertanian.html diakses 11 Desember 2015.

\section{Anonymous,(2008).Teori-Teori}

Pertanian.

http://informasi34.blogspot.co.id/

2008/12/teori-teori

pertanian.html,akses tanggal 28 Juni 2016.

Arikunto Suharsimi.(2010). Prosedur Penilitian.Jakarta:Rineka Cipta

Asev Didin Wahyudinata.(2013) Informasi Teknologi Pertanian.http://asevdinatha.blogsp ot.co.id/2013/07/definisipertanian.html diakses 17 Desember 2015.

Cinta Lestari.(2013).Pengertian Penjualan.http://pengertianbahasa.b logspot.co. id/2013/02/pengertianpenjualan.html.di akses 13 Desember 2015.

\section{Elian.(2014) Penggunaan Internet Dan} Pemanfaatan Informasi Pertanian Oleh Penyuluh Pertanian Di Kabupaten Bogor Wilayah Barat. Bogor: Jurnal Komunikasi Pembangunan

Firdaus Muhammad.(2012). Manaje men Agribisnis.Jakarta:Bumi Aksara

Hutabarat Hermanto,(2013). Analisis Faktor-Faktor yang mempe ngaruhi petani dalam Pen jualan Padi ke Tengkulak di Kecamatan Jatilawang Kabupaten Banyumas:Jurnal Akademik Pertanian HKTI Banyumas.diakses 12 Februari 2016.

Hagani.S,(2008).Pemberdayaan

Tengkulak Untuk Mening katkan 


\section{kesejahteraan}

Petani.https://

suwardihagani.wordpress.com/tag/de ptan/ diakses tanggal 27 Juli 2016.

Irwan Sahaja,(2014).Volume, Tujuan,dan

Faktor yang Mempengaruhi

Penjualan.http://irwansahaja.blogspo

t.co.id/2014/05/volume-tujuan-dan-

faktor-yang.html.diakses tanggal 12

Desember 2015.

Mardianto et.al.(2005) Dinamika Pola

Pemasaran Gabah dan Beras di

Indonesia. Bogor : Jurnal Forum

Penilitian Agro Ekonomi. diakses 12

Februari 2016.

Maun.M.Ariyanti.(2002)

Organizational

Hubungan

Informasi Pasar, Inovasi Dan

Kinerja Pasar. Semarang: Jurnal

Sains Pemasaran Indonesia. diakses 12 Februari 2016.

Mubyarto.(1989). Pengantar Ekonomi

Pertanian.Jakarta:LP3ES

Saihani,(2011). Analisis Faktor Sosial

Ekonomi Terhadap Pendapatan

Petani Padi Ciherang Di Desa

Sungai Durait Tengah Kecamatan

Babirik Kabupaten Hulu Sungai
Utara. Amuntai : Jurnal Ziraa'ah. diakses 12 Februari 2016.

Soekartawi,(2006). Analisis Usahatani. Jakarta: Universitas Indonesia (UIPress)

Sriwijayanti.S(2010). Lembaga

Pemasaran,

https://sriwijayanti.wordpres.com/ lembaga -pemasaran/diakses 14 Januari 2016.

Sumarwan Ujang.(2015). Perilaku Kunsumen. Bogor:Ghalia Indonesia

Sunyoto Danang,(2014).Dasar-Dasar Manajemen Pemasaran.Yogyakarta :CAPS (Center of Akademic Publishing Service).

Wulandari. (2014) Kondisi Sosial Ekonomi Petani Padi Sawah Di Kelurahan Mangalli Kecamatan Pallangga Kabupaten Gowa Makassar: Skripsi S1,Fakultas Ilmu Sosial Dan Ilmu Politik, Universitas Hasanuddin. diakses 18 Februari 2016. 